\title{
Study on the color levelness of silk fabric dyed with vegetable dyes
}

\author{
Mohammad Gias Uddin*
}

\begin{abstract}
At present, customers are more conscious about the quality of clothing items. As a result, it becomes more challenging for the manufacturers to maintain the consistent dyeing quality. Unlevelness is generally unaccepted in commercial dyeing, except some cases such as stone-washed, acid-washed or pigment-dyed textiles. The aim of the study was to evaluate the color levelness quality of fabric dyed with vegetable dyes. For this purpose, dyeing was carried out on silk fabric with the aqueous extracts of mango, guava and henna leaves. Then the levelness of colored fabric was evaluated by spectrophotometric measurements in terms of color difference, $\Delta \mathrm{E}$ value. It was concluded that unmordanted dyed samples have better color levelness quality than the mordanted ones. The unmordanted samples dyed with mango and guava leaves extracts showed excellent levelness quality while the unmordanted ones dyed with henna leaves extracts showed good levelness quality. On the other hand, the mordanted dyed samples showed good leveling quality for the three vegetable dyes except ferrous sulphate mordanted sample dyed with henna leaves extract. Again, among the mardanted samples the levelness quality was comparatively better in case of alum mordanted dyed samples and the average $\Delta \mathrm{E}$ value was increased gradually when moved from alum to tin and finally to ferrous sulphate.
\end{abstract}

Keywords: Color levelness, Vegetable dyes, $\Delta$ E value, Silk fabric, Uniformity of shade, Mordants

\section{Background}

The vegetable dyes are generally used for the coloration of the products in textile and fashion industries (For yarns, fabrics and garments), food industry (For sweets, confectionery and bakery products), and cosmetics industry (For soap, cream, powder, lipstick etc.). There is a big potential for using the vegetable dyes in textile industry due to one and only reason i.e. eco-friendliness of the product $[1,2]$. Whole plant (e.g. weld/marigold), barks (e.g. oak/maple), leaves (e.g. tea/henna), seeds (e.g. annatto), roots (e.g. madder/blood root), semen shell (e.g. Persian nut), flowers (e.g. dahlia/gul mohar), rhizome (e.g. water lily), fruits (e.g. elder berries), fruit rinds (e.g. pomegranate) or, skin (e.g. onion) etc. can be the sources of vegetable dyes [3]. The use of vegetable materials in textile coloration is a well-known way of utilizing renewable raw materials according to the technical and

*Correspondence: giasdtt@gmail.com

Department of Textile Engineering, Ahsanullah University of Science and Technology, Dhaka 1208, Bangladesh ecological requirements of the $21^{\text {st }}$ Century [4]. For this purpose, traditional dye plants have also been cultivated in many countries. As an estimate $1 \mathrm{~kg}$ of plant material will be required to dye $1 \mathrm{~kg}$ of textile goods, this indicates that the use of vegetable dyes including secondary products will be cost effective [5]. Many dyes can be easily available from garden waste. In many of the world's developing countries, vegetable sources not only give final products with a great variety of shades but also the possibility of an income through sustainable harvest and sale of these plants [6]. Many of the vegetable dyes attract the most consumers with a special fragrance and many provide antibacterial and UV protective functions to fabrics $[7,8]$.

However, with the increased interest in vegetable dyes a greater importance was given on using mordant. Most of these dyes require some sort of mordant to set permanently in the fibers. Metal ions of mordants which are widely used act as electron acceptors for electron donors to form coordination bonds with the dye molecules, making them insoluble in water $[9,10]$. This leads to improve

\section{Chemistry Central}


dye uptake and retention, which result in a greater depth of shade and color fastness properties [11]. Common mordants used are alum, ferrous sulphate, stannous chloride etc. [12].

Day by day the customers are going to be more conscious about the quality of clothing items. As a result, it becomes more challenging for the manufacturer to maintain the consistent dyeing quality. Unlevelness is generally unaccepted in commercial dyeing, except for stone-washed, acid-washed or pigment-dyed textiles, where an effect is sought to comply with a fashion trend. Color levelness is actually a description of the uniformity of shade in different places of the fabric. Traditionally it is judged by visual assessment, or by comparing similar samples, e.g. from the same fabric batch, to determine color differences. The human eyes can detect small differences in color, but it is difficult to quantify color differences accurately. Textile manufacturing industries are mainly concerned with the appearance of color uniformity in terms of levelness parameters in dyed fabrics and/ or union shade in dyed fabrics of more than one fiber type [13]. Since mordants are also used in the processing of vegetable dyes, unlevelness could be a major problem in textile dyeing and dyeing with the vegetable sources should have proper control over color levelness.

\section{Methods}

\section{Materials}

The raw silk fabric (1/1 plain weave and $\left.22 \mathrm{~g} / \mathrm{m}^{2}\right)$ purchased from Sopura Silk Ltd., Dhaka was used in this study.

\section{Methods}

\section{Pre-treatment}

The raw silk fabric was degummed in an aqueous soap solution (15 g/L soap) at $\mathrm{pH} 9$, material to liquor ratio 1:50, and temperature $80^{\circ} \mathrm{C}$ for $60 \mathrm{~min}$. The degummed fabric was washed with $2 \mathrm{~g} / \mathrm{L}$ detergent at $65^{\circ} \mathrm{C}$ for $10 \mathrm{~min}$. Then, the fabric was treated with $35 \%$ hydrogen peroxide $(3 \mathrm{~mL} / \mathrm{L})$ solution, maintaining a material to liquor ratio of $1: 50$ at $\mathrm{pH} 9$ and temperature $60^{\circ} \mathrm{C}$ for $60 \mathrm{~min}$ followed by wash with $2 \mathrm{~g} / \mathrm{L}$ detergent at $65^{\circ} \mathrm{C}$ for $10 \mathrm{~min}$. Mordanting was carried out using 5\% (On fabric weight) of ferrous sulphate $\left(\mathrm{FeSO}_{4}\right)$, alum $\left[\mathrm{KAl}\left(\mathrm{SO}_{4}\right)_{2} \cdot 12 \mathrm{H}_{2} \mathrm{O}\right]$, tin $\left(\mathrm{SnCl}_{2}\right)$ mordants individually and using three different combinations of mordants such as ferrous sulphate-alum $(2.5 \%+2.5 \%)$, ferrous sulphate-alum-tin $(2 \%+2 \%+1 \%)$ and alum-tin $(2.5 \%+2.5 \%)$ at $60^{\circ} \mathrm{C}$ for 60 min keeping material to liquor ratio 1:30.

\section{Dyeing}

Extraction of the coloring component from vegetable leaf sources-mango, guava and henna leaves was carried out in aqueous boiling process. It was done by extracting fixed quantity of powdered leaves with a material to liquor ratio of 1:10 (Weight of leaves powder in g; amount of water in $\mathrm{mL}$ ) at boil for $60 \mathrm{~min}$. Dyeing was carried out in exhaust method with the dye extracts as per standard dyeing conditions recommended for silk fabric [14] at $80^{\circ} \mathrm{C}$ for 60 min under $\mathrm{pH} \mathrm{5,} \mathrm{keeping} \mathrm{material} \mathrm{to} \mathrm{liquor}$ ratio 1:50 in a IR sample dyeing machine.

\section{Color difference, $\Delta E$}

Each dyed sample is measured in a dual beam reflectance spectrophotometer (Datacolor 650, USA) using $\mathrm{D}_{65}$ illuminant and $10^{\circ}$ observer settings considering the reading- 1 as standard and other nines as sample batches. Data for each batch are analyzed with respect to color difference, $\Delta \mathrm{E}$ value. $\Delta \mathrm{E}$ is a single value that takes into account the differences between the $\mathrm{L}^{*}, \mathrm{a}^{*}$ and $\mathrm{b}^{*}$ values of the sample and standard in the CIE L"a"b* color system. The Eq. 1 was used to calculate the $\Delta \mathrm{E}[15]$.

$$
\left.\Delta \mathrm{E}=\sqrt{\left[\left(\Delta \mathrm{L}^{*}\right)^{2}+\left(\Delta \mathrm{a}^{*}\right)^{2}+\left(\Delta \mathrm{b}^{*}\right)^{2}\right.}\right]
$$

$\Delta \mathrm{L}^{*}=\mathrm{L}^{*}$ sample $-\mathrm{L}^{*}$ standard, $\Delta \mathrm{a}^{*}=\mathrm{a}^{*}$ sample $-\mathrm{a}^{*}$ standard, $\Delta \mathrm{b}^{*}=\mathrm{b}^{*}$ sample $-\mathrm{b}^{*}$ standard; where standard refers to the reading- 1 in dyed fabric, sample refers to other readings in the corresponding dyed fabric.

The $\Delta \mathrm{E}$ value is an important parameter in the dyeing process, which can indicate degree of levelness of dyed fabric. For the study, the degree of levelness was described according to $\Delta \mathrm{E}$ values as shown in Table 1 .

\section{Results and discussion}

\section{Levelness of the dyed samples}

The $\Delta E$ values of silk fabric dyed with henna, guava and mango leaves extracts using different mordants were shown in Table 2.

From Table 2, it was found that levelness was found highest when no mordant was used on the fabric as the average $\Delta \mathrm{E}$ value was the lowest for all the three vegetable dyes in such cases.

In case of mango leaves dyed fabric, when no mordant was used, the minimum average $\Delta \mathrm{E}$ value was found 0.14 among all the results and in this case, maximum levelness

\section{Table 1 Suggested interpretation of $\Delta E$ values}

\begin{tabular}{|c|c|c|}
\hline$\Delta E$ value & $\begin{array}{l}\text { Visual appearance } \\
\text { of levelness }\end{array}$ & Extent of unlevelness \\
\hline$\leq 0.20$ & Excellent levelness & Unlevelness not detectable \\
\hline $0.21-0.50$ & Good levelness & $\begin{array}{l}\text { Unlevelness noticeable under } \\
\text { close examination }\end{array}$ \\
\hline $0.51-1.0$ & Poor levelness & Apparent unlevelness \\
\hline$>1.0$ & Bad levelness & Conspicuous unlevelness \\
\hline
\end{tabular}


Table $2 \Delta E$ values of silk fabrics dyed with vegetable dyes

\begin{tabular}{|c|c|c|c|c|c|c|c|c|c|c|c|c|}
\hline \multirow[t]{3}{*}{ Dye sources } & \multirow[t]{3}{*}{ Mordant type } & \multicolumn{10}{|c|}{$\Delta \mathrm{E}$ values of dyed samples } & \multirow{3}{*}{$\begin{array}{l}\text { Average } \\
\Delta \mathrm{E}\end{array}$} \\
\hline & & R-1 & & $\mathrm{R}-3$ & $\mathrm{R}-4$ & R-5 & R-6 & R-7 & $\mathrm{R}-8$ & R-9 & $\mathrm{R}-10$ & \\
\hline & & & \multicolumn{9}{|c|}{ Batch readings } & \\
\hline \multirow[t]{7}{*}{ Mango leaves } & No mordant & Standard & 0.19 & 0.17 & 0.07 & 0.22 & 0.10 & 0.21 & 0.09 & 0.12 & 0.10 & 0.14 \\
\hline & $\mathrm{FeSO}_{4}$ & & 0.45 & 0.24 & 0.37 & 0.42 & 0.56 & 0.22 & 0.32 & 0.41 & 0.61 & 0.40 \\
\hline & $\mathrm{FeSO}_{4}$-Alum & & 0.28 & 0.42 & 0.32 & 0.26 & 0.61 & 0.37 & 0.35 & 0.27 & 0.22 & 0.34 \\
\hline & $\mathrm{FeSO}_{4}$-Alum-Tin & & 0.29 & 0.24 & 0.13 & 0.34 & 0.32 & 0.22 & 0.55 & 0.14 & 0.56 & 0.31 \\
\hline & Alum & & 0.19 & 0.30 & 0.18 & 0.25 & 0.12 & 0.32 & 0.43 & 0.27 & 0.15 & 0.25 \\
\hline & Alum-Tin & & 0.39 & 0.23 & 0.25 & 0.19 & 0.45 & 0.34 & 0.27 & 0.13 & 0.17 & 0.27 \\
\hline & Tin & & 0.24 & 0.15 & 0.39 & 0.17 & 0.15 & 0.51 & 0.38 & 0.11 & 0.25 & 0.26 \\
\hline \multirow[t]{7}{*}{ Guava leaves } & No mordant & & 0.12 & 0.27 & 0.15 & 0.13 & 0.03 & 0.42 & 0.21 & 0.14 & 0.24 & 0.19 \\
\hline & $\mathrm{FeSO}_{4}$ & & 0.49 & 0.54 & 0.36 & 0.68 & 0.56 & 0.55 & 0.29 & 0.30 & 0.46 & 0.47 \\
\hline & $\mathrm{FeSO}_{4}$-Alum & & 0.54 & 0.37 & 0.56 & 0.24 & 0.38 & 0.34 & 0.26 & 0.34 & 0.18 & 0.36 \\
\hline & $\mathrm{FeSO}_{4}$-Alum-Tin & & 0.21 & 0.20 & 0.18 & 0.45 & 0.24 & 0.43 & 0.49 & 0.51 & 0.43 & 0.35 \\
\hline & Alum & & 0.08 & 0.24 & 0.14 & 0.21 & 0.13 & 0.33 & 0.05 & 0.38 & 0.51 & 0.23 \\
\hline & Alum-Tin & & 0.48 & 0.29 & 0.07 & 0.23 & 0.24 & 0.30 & 0.09 & 0.17 & 0.28 & 0.23 \\
\hline & Tin & & 0.31 & 0.64 & 0.34 & 0.17 & 0.18 & 0.23 & 0.54 & 0.43 & 0.22 & 0.34 \\
\hline \multirow[t]{7}{*}{ Henna leaves } & No mordant & & 0.29 & 0.22 & 0.11 & 0.20 & 0.16 & 0.17 & 0.33 & 0.18 & 0.24 & 0.21 \\
\hline & $\mathrm{FeSO}_{4}$ & & 0.75 & 0.23 & 0.45 & 0.57 & 0.48 & 0.62 & 0.79 & 0.33 & 0.55 & 0.53 \\
\hline & $\mathrm{FeSO}_{4}$-Alum & & 0.34 & 0.37 & 0.24 & 0.23 & 0.42 & 0.37 & 0.30 & 0.13 & 0.54 & 0.33 \\
\hline & $\mathrm{FeSO}_{4}$-Alum-Tin & & 0.35 & 0.26 & 0.58 & 0.40 & 0.41 & 0.43 & 0.13 & 0.43 & 0.42 & 0.38 \\
\hline & Alum & & 0.13 & 0.25 & 0.21 & 0.16 & 0.53 & 0.51 & 0.17 & 0.27 & 0.19 & 0.27 \\
\hline & Alum-Tin & & 0.46 & 0.35 & 0.12 & 0.34 & 0.18 & 0.23 & 0.24 & 0.25 & 0.63 & 0.31 \\
\hline & Tin & & 0.32 & 0.53 & 0.19 & 0.36 & 0.20 & 0.24 & 0.11 & 0.32 & 0.23 & 0.28 \\
\hline
\end{tabular}

was found which can be expressed as excellent levelness i.e., unlevelness was not detectable (See Table 1). In addition, when mordants were used, all the average $\Delta \mathrm{E}$ values were found within $0.21-0.50$ range and can be described as good leveling i.e., unlevelness was noticeable under close examination. Among the mordanted samples dyed with mango leaves extracts, the order of levelness found was: alum $(0.25)>\operatorname{tin}(0.26)>$ alum-tin $(0.27)>$ ferrous sulphate-alum-tin $(0.31)>$ ferrous sulphate-alum $(0.34)>$ ferrous sulphate $(0.40)$.

Again, in case of guava leaves dyed fabric, the minimum average $\Delta \mathrm{E}$ value was found 0.19 when no mordant was used and in this case, maximum levelness was found which can be expressed as excellent levelness. When mordants were used, all the average $\Delta \mathrm{E}$ values of guava leaves dyed fabric were found within $0.21-0.50$ range and can be described as good leveling. Among the mordanted samples dyed with guava leaves extracts, the order of levelness found was: alum and alum-tin $(0.23)>$ tin $(0.34)>$ ferrous sulphate-alum-tin $(0.35)>$ ferrous sulphate-alum $(0.36)>$ ferrous sulphate $(0.47)$.

Moreover, in case of henna leaves dyed fabric, good levelness was found when no mordant was used, as the average $\Delta \mathrm{E}$ value was found 0.21 . But except the ferrous sulphate mordanted dyed sample, all the mordanted dyed samples showed the average $\Delta \mathrm{E}$ value within $0.21-0.50$ range i.e., good levelness. For ferrous sulphate mordanted dyed sample the average $\Delta \mathrm{E}$ value was found highest (0.53). It can be interpreted as sample of poor levelness quality i.e., showing some kind of apparent unlevelness. Thus among the mordanted samples dyed with henna leaves extracts, the order of levelness found was: alum $(0.27)>$ tin $(0.28)>$ alum-tin $(0.31)>$ ferrous sulphatealum $(0.33)>$ ferrous sulphate-alum-tin $(0.38)>$ ferrous sulphate (0.53).

Thus, among the fabrics dyed with the three vegetable dyes, the noticeable trend found was unmordanted dyed sample showed better levelness than mordanted dyed samples and among the mardanted samples the levelness quality was comparatively better in case of alum mordanted dyed samples and the average $\Delta \mathrm{E}$ value was found increased gradually when moved from alum to tin and finally to ferrous sulphate.

The phenomenon of levelness or unlevelness can be interpreted mainly by the homogeneity of the dye distribution on the fabrics dyed with the vegetable dyes. The reason behind the better levelness of the unmordanted samples was due to homogeneity of the dye distribution 
on the fabric, while non-homogenous distribution of the dyes can result in the greater $\Delta \mathrm{E}$ values. In addition, ferrous sulphate as a transition metal mordant forms a large number of complexes with the dye molecules, mostly octahedral ones with coordination number 6 . As a result, ferrous sulphate salts can form a ternary complex on one site with the fiber and in the other site with the dye, which resulted in slightly higher color difference.

\section{Conclusions}

This study was carried out to evaluate the color levelness of silk fabric dyed with mango, guava and henna leaves extracts and the differences among $\Delta \mathrm{E}$ values obtained from different areas of fabric were used for such evaluation. It was concluded that unmordanted dyed samples have better color levelness quality than the mordanted ones. The unmordanted samples dyed with mango and guava leaves extracts showed excellent levelness quality while the unmordanted ones dyed with henna leaves extracts showed good levelness quality. On the other hand, in case of mordanted samples dyed with mango leaves extracts, the order of color levelness found was: alum $>$ tin $>$ alum-tin $>$ ferrous sulphate-alum-tin $>$ ferrous sulphate-alum $>$ ferrous sulphate. Among the mordanted samples dyed with guava leaves extracts, the order found was: alum and alum-tin $>$ tin $>$ ferrous sulphatealum-tin $>$ ferrous sulphate-alum $>$ ferrous sulphate. Thus among the mordanted samples dyed with henna leaves extracts, the order found was: alum $>$ tin $>$ alumtin $>$ ferrous sulphate-alum $>$ ferrous sulphate-alumtin $>$ ferrous sulphate. It was found that all the mordanted dyed samples showed good leveling quality for the three vegetable dyes except ferrous sulphate mordanted sample dyed with henna leaves extract. Except this one, it was concluded that good to excellent leveling quality was achieved on silk fabric dyed with three vegetable leaf dyes.
Received: 26 May 2015 Accepted: 25 June 2015

Published online: 07 July 2015

\section{References}

1. Adeel S, Fazal-ur-Rehman, Hanif R, Zuber M, Ehsan-ul-haq, Munir M (2014) Ecofriendly dyeing of UV-irradiated cotton using extracts of acacia nilotica bark (kikar) as source of quercetin. Asian J Chem 26(3):830-834

2. Naz S, Bhatti IA, Adeel S (2011) Dyeing properties of cotton fabric using un-irradiated and gamma irradiated extracts of Eucalyptus camaldulensis bark powder. Indian J Fibre Text Res 36(2):132-136

3. Ahmed WYW, Rahim R, Ahmad MR, Kadir MIA, Misnon MI (2011) The application of Gluta Aptera wood (Rengas) as natural dye on silk and cotton fabrics. Univers J Environ Res Technol 1(4):545-551

4. Tayade PB, Adivarekar RV (2013) Dyeing of silk fabric with Cuminum $L$ as a source of natural dye. Int J ChemTech Res 5(2):699-700

5. Bechtold T, Mussak R (eds) (2009) Handbook of natural colorants. Wiley, West Sussex

6. Jothi D (2008) Extraction of natural dyes from African marigold flowers (Tagetes Ereectal) for textile coloration. AUTEX Res J 8(2):49-53

7. Khan AA, lqbal N, Adeel S, Azeem M, Batool F, Bhatti IA (2014) Extraction of natural dye from red calico leaves: gamma ray assisted improvements in color strength and fastness. Dyes Pigm 103:50-54

8. Ajmal M, Adeel S, Azeem M, Zuber M, Akhtar N, lqbal N (2014) Modulation of pomegranate peel colorant characteristics for textile dyeing using energy radiations. Ind Crops Prod 58:188-193

9. Uddin MG (2014) Effects of different mordants on silk fabric dyed with onion outer skin extracts. J Textiles 2014:1-8 (Article ID 405626)

10. Zarkogianni M, Mikropoulou E, Varella E, Tsatsaroni E (2010) "Color and fastness of natural dyes: revival of traditional dyeing techniques", Society of Dyers and Colorists. Color Technol 127:18

11. Win ZM, Swe MM (2008) Purification of the natural dyestuff extracted from Mango bark for the application on protein fibers. World Acad Sci Eng Technol 22:536-540

12. Saravanan $P$, Chadramohan G (2011) Dyeing of silk with ecofriendly natural dye obtained from Barks of Ficus Religiosa. L. Univ J Environ Res Technol 1(3):268-273

13. Yang Y, Li S (1993) Instrumental measurement of the levelness of textile coloration. Text Chem Color 25(9):75-78

14. Clariant manual. Recommendations for dyeing silk. Sandoz Chemicals, Basel. (ID-05543.00.94)

15. Millward S (2009) Color difference equations and their assessment. Test Target J 9:19-26

\section{Compliance with ethical guidelines}

\section{Competing interest}

The author declares that he has no competing interest.

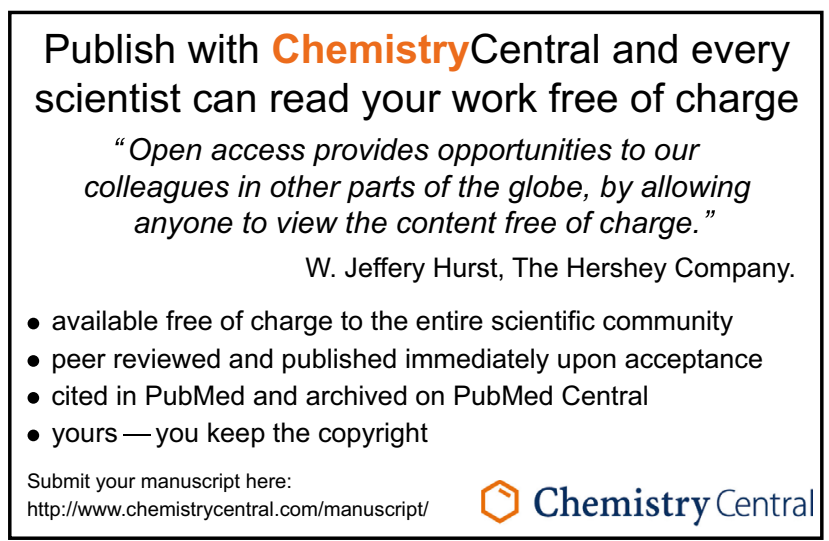

